\title{
The Effect of Concentration of Lawsonia inermis as a Corrosion Inhibitor for Aluminum Alloy in Seawater
}

\author{
F. Zulkifli, ${ }^{1}$ Nora'aini Ali, ${ }^{1}$ M. Sukeri M. Yusof, ${ }^{2}$ Wan M. Khairul, ${ }^{2}$ \\ Rafizah Rahamathullah, ${ }^{2}$ M. I. N. Isa, ${ }^{2}$ and W. B. Wan Nik ${ }^{1}$ \\ ${ }^{1}$ School of Ocean Engineering, Universiti Malaysia Terengganu, 21030 Kuala Terengganu, Terengganu, Malaysia \\ ${ }^{2}$ School of Fundamental Science, Universiti Malaysia Terengganu, 21030 Kuala Terengganu, Terengganu, Malaysia \\ Correspondence should be addressed to W. B. Wan Nik; niksani@umt.edu.my
}

Received 11 October 2016; Revised 2 January 2017; Accepted 23 January 2017; Published 16 February 2017

Academic Editor: Claudio Fontanesi

Copyright (C) 2017 F. Zulkifli et al. This is an open access article distributed under the Creative Commons Attribution License, which permits unrestricted use, distribution, and reproduction in any medium, provided the original work is properly cited.

\begin{abstract}
Lawsonia inermis also known as henna was studied as a corrosion inhibitor for aluminum alloy in seawater. The inhibitor has been characterized by optical study via Fourier transform infrared spectroscopy (FTIR). The FTIR proves the existence of hydroxyl and carbonyl functional groups in Lawsonia inermis. Aluminum alloy 5083 immersed in seawater in the absence and presence of Lawsonia inermis was tested using electrochemistry method, namely, electrochemical impedance spectroscopy (EIS) and potentiodynamic polarization (PP). EIS and PP measurements suggest that the addition of Lawsonia inermis has caused the adsorption of inhibitor on the aluminum surface. The adsorption behavior of the inhibitor follow Langmuir adsorption model where the value of free energy of adsorption, $-\Delta G$, is less than $40 \mathrm{~kJ} / \mathrm{mol}$ indicates that it is a physical adsorption. Finally, it was inferred that Lawsonia inermis has a real potential to act as a corrosion inhibitor for aluminum alloy in seawater.
\end{abstract}

\section{Introduction}

Recently, eco-friendly and biodegradable commodities have caused a shift towards the use of natural product instead of using toxic materials [1]. Furthermore, natural products derived from various flora and fauna are believed to be safe due to their nontoxic, noncarcinogenic, and biodegradable nature [2-4]. Heavy metals such as lead $(\mathrm{Pb})$ which are produced from industry (painting, charcoal burning, and leaded gasoline) are known to be a threat to the marine environment [5]. A previous research has employed Thymus vulgaris as a corrosion inhibitor for stainless steel in acidic solution [6]. The findings show that the inhibitor efficiency increases as the concentration increase. A very similar finding was obtained by the other researchers using various plant extracts such as Piper longum, Griffonia simplicifolia, alba pendula, and tobacco rob [7-10].

Lawsonia inermis (henna) could become one of the potential natural materials for anticorrosion due to its application for more than 5000 years as hair and skin pigments due to its excellent dye property $[11,12]$. The presence of 2-hydroxy-1,4-naphthoquinone attributes to the important activities such as antioxidant, anti-inflammatory, anticancer, and anticorrosion [13-15]. Lawsonia inermis exhibits an exquisite inhibition effect towards corrosion [16-18]. Polarization technique was used to characterize the aqueous extract of the henna leaves as a corrosion inhibitor of carbon steel, nickel, and zinc in acidic, neutral, and alkaline solutions reported elsewhere [19].

The mechanism of the organic inhibitor is usually an adsorption process. The heteroatom in the inhibitor's molecule acts as an active site for the adsorption to take place. The physical and chemical properties of inhibitor molecule influence the adsorption process and this is related to the electronic density of donor atoms and the possible steric effects [20]. Furthermore, the nature of metal surface, the chemical composition of the corrosive medium, and temperature of the reaction and on the electrochemical potential at the metal/solution interface also manipulate the adsorption process [21]. Nevertheless, to the best of author's knowledge, the study of Lawsonia inermis as a corrosion inhibitor has never been employed to aluminum alloy in seawater. 
TABLE 1: Composition of aluminium alloy 5083 (AA5083).

\begin{tabular}{lcccccccccc}
\hline Element & $\mathrm{Mg}$ & $\mathrm{Mn}$ & $\mathrm{Fe}$ & $\mathrm{Si}$ & $\mathrm{Zn}$ & $\mathrm{Cr}$ & $\mathrm{Ti}$ & $\mathrm{Cu}$ & $\mathrm{Al}$ \\
\hline Weight percent, wt\% & 4.5 & 0.7 & 0.4 & 0.4 & 0.25 & 0.15 & 0.15 & 0.1 & Remaining \\
\hline
\end{tabular}

In marine industry, metals like aluminum alloy play tremendous roles in which they are used widely for shipbuilding, chemical plant, and offshore structure [22, 23]. The increasing sector demand for higher speed performances and cheap assembly technology has made aluminum alloy as one of the best choices as a structural material for boats, vessels, and components $[24,25]$. The advantages of aluminum in many ways have propelled it into one of the widely used metals in the marine industries.

To better understand the inhibitive behavior of natural products, Lawsonia inermis as corrosion inhibitor was investigated via electrochemical impedance spectroscopy and potentiodynamic polarization. Meanwhile, the optical study was conducted by using Fourier transform infrared (FTIR) and the quantum chemical calculation was done to determine the synergism behavior of the inhibitor.

\section{Experimental}

2.1. Surface Preparation of Aluminum Alloy 5083 (AA5083). AA5083 with the dimension of $25 \mathrm{~mm} \times 25 \mathrm{~mm} \times 3 \mathrm{~mm}$ was polished by using emery paper with different grades $(600$, 900 , and 1200). Then the samples were cleaned with acetone and rinsed with distilled water, dried in air, and then stored in desiccators prior to use. Table 1 shows the composition of AA5083 [26].

2.2. Extraction of Lawsonia inermis (Henna). The fresh leaves of Lawsonia inermis were dried at room temperature and then crushed into powder form. Lawsonia inermis powder was mixed with ethanol and left for a week. Then, the mixture was extracted by means of the rotary evaporator. The residue left in the flush was used directly by diluting it to 20 liters of seawater with respect to inhibitor concentration. Seawater was collected at Universiti Malaysia Terengganu beachfront. The composition of South China Sea seawater is shown in Table 2.

2.3. Fourier Transform Infrared Analysis (FTIR) and Ultraviolet Visible Spectroscopy (UV-Vis). FTIR was carried out using Thermo Nicolet 380 FTIR Spectrometer. The spectrometer was used to identify the functional groups of Lawsonia inermis by observing at the vibrational motion of bonds in the molecule. An infrared light was passing through the sample that was placed on the germanium crystal. The frequency was ranging from 4000 to $675 \mathrm{~cm}^{-1}$ with spectra resolution of $4 \mathrm{~cm}^{-1}$ following the work done as reported elsewhere [27]. The FTIR data was recorded in the transmittance mode. The transmittance and reflectance of the infrared rays at different frequencies were translated into an IR absorption plot consisting of reverse peaks. The spectral pattern was analyzed and matched according to IR absorption table to identify the functional group contained in the Lawsonia
TABle 2: Composition of seawater from South China Sea.

\begin{tabular}{lc}
\hline Parameter & Reading \\
\hline $\mathrm{pH}$ & 7.492 \\
Temperature $\left({ }^{\circ} \mathrm{C}\right)$ & 29.46 \\
Conductivity $(\mathrm{mS} / \mathrm{cm})$ & 52.56 \\
Salinity $(\mathrm{ppt})$ & 31.58 \\
Dissolved oxygen $(\mathrm{mg} / \mathrm{L})$ & 7.086 \\
Turbidity $(\mathrm{NTU})$ & 0.05 \\
\hline
\end{tabular}<smiles>O=C1C=C(O)C(=O)c2ccccc21</smiles>

FIGURE 1: Molecular structure of Lawsonia inermis.

inermis. Figure 1 shows the molecule structure of lawsone that is the central component in Lawsonia inermis [16, 28].

A UV-Vis measurement was performed using an in-house built cell which allowed the transmission of light through the cell. UV/Vis spectroscopy (Lambda 265, Perkin Elmer) recorded the absorbance between $200-800 \mathrm{~nm}$ in transmission mode where ethanol was used as the background.

2.4. Electrochemical Impedance Spectroscopy (EIS). EIS was used to study the impedance characteristic as well as capacitance behavior of AA5083 in the presence and absence of henna. The EIS measurement was performed by using alternating current (AC) signal of impedance measurements by means of Autolab PGSTAT302N with respect to the open circuit potential (OCP). All the potentials referred were relative to saturated calomel electrode (SCE). The impedance measurements used a frequency range of $1 \mathrm{kHz}$ down to $10 \mathrm{mHz}$. The results were analyzed using the fit program of NOVA 1.10.

Open circuit potential (OCP) measurement was conducted to investigate the potential of electrode at various temperatures. OCP was run for $1800 \mathrm{~s}$ while the limit $d V / d t$ was set to $1 \mu \mathrm{V} / \mathrm{s}$. The average potential was taken as the OCP of the electrode.

2.5. Potentiodynamic Polarization (PP). Potentiodynamic polarization (PP) is the most common polarization method used for measuring corrosion resistant. The cell used was a conventional three electrodes with a platinum wire counter electrode (CE) and $\mathrm{Ag} / \mathrm{AgCl}$ as a reference electrode (RE). The working electrode (WE) is in the form of a square 
cut so that the flat surface would be the only surface in the electrode. The potentiodynamic current-potential curves recorded the data after the electrode potential was automatically changed from $-200 \mathrm{mV}$ to $+200 \mathrm{mV}$ with the scanning rate of $10 \mathrm{mVs}^{-1}$. The results were analyzed and fitted using NOVA 1.10 program. Corrosion current density $\left(i_{\text {corr }}\right)$ was calculated by using a validated Stern-Geary equation [29] as shown in (1) where $b_{a}$ is anodic Tafel slope, $b_{c}$ is cathodic Tafel slope, and $R_{p}$ is the polarization resistance:

$$
i_{\text {corr }}=\frac{b_{a} \times b_{c}}{2.303 R_{p}\left(b_{a}+b_{c}\right)} .
$$

2.6. Inhibition Efficiency ( $\eta$ ). Inhibition efficiency $(\eta)$ was calculated based on the findings gained from EIS and PP measurements. The calculated value of $\eta$ from EIS method was done by employing (2), where $R_{\mathrm{ct}(\text { inhibitor) }}$ is the charge transfer resistance in the presence of inhibitor while $R_{\mathrm{ct}}$ is the charge transfer resistance in the absence of inhibitor:

$$
\eta(\%)=\frac{R_{\mathrm{ct}(\text { inhibitor })}-R_{\mathrm{ct}}}{R_{\mathrm{ct} \text { (inhibitor) }}} \times 100 \% .
$$

The value of $i_{\text {corr }}$ was used to determine the inhibition efficiency of Lawsonia inermis based on

$$
\eta(\%)=\frac{i_{\text {corr }}-i_{\text {corr(inhibitor) }}}{i_{\text {corr }}} \times 100 \%,
$$

where $i_{\text {corr }}$ is the corrosion current density in the absence of inhibitor and $i_{\text {corr(inhibitor) }}$ is the corrosion current density in the presence of inhibitor.

2.7. Adsorption Isotherm. To understand the adsorption mode of the corrosion resistance on the surface of AA5083, the data obtained from the three different techniques were tested with several adsorption isotherms models including Langmuir, Frumkin, and Temkin. The surface coverage, $\theta$, was calculated by following equation where $\eta$ is the inhibition efficiency:

$$
\theta=\frac{\eta(\%)}{100(\%)} .
$$

The plots of concentration $(C)$ versus concentration/surface coverage $(C / \theta)$ were plotted to determine the thermodynamic parameter.

\section{Results and Discussion}

3.1. Fourier Transform Infrared (FTIR). FTIR method determines the type of vibrational band presence in Lawsonia inermis. Lawsonia inermis is known to contain various constituents such as lawsone, flavonoids, gallic acid, and tannin [30].

Infrared spectrum for Lawsonia inermis reveals two major expected frequency regions of the band of interest namely hydroxyl $(\mathrm{OH})$ and carbonyl $(\mathrm{C}=\mathrm{O})$. Lawsone (2-hydroxy, 1,4-naphthoquinone) is represented by the hydroxyl group. A

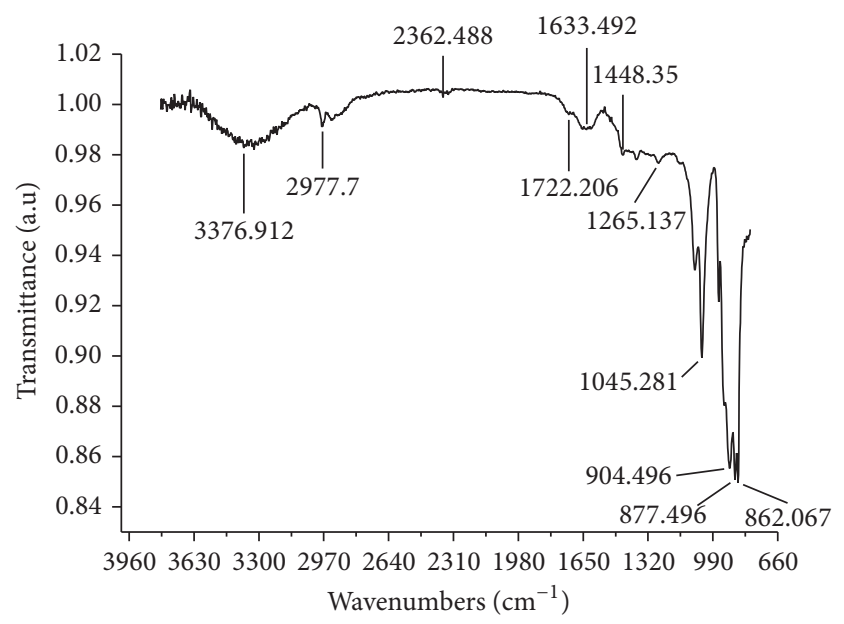

FIGURE 2: FTIR spectrum of Lawsonia inermis.

broadband centered at $3376 \mathrm{~cm}^{-1}$ in Figure 2 was attributed to the stretching vibration of the hydroxyl group which can be found at the first lawsone aromatic ring [31,32]. The broad absorbance is due to the intramolecular hydrogen bonding between the $\mathrm{OH}$ group and adjacent oxygen atom. Lawsone and tannin which were represented by hydroxyl and carbonyl functional group improved Lawsonia inermis performance as chelating agent [33].

Quinones usually exhibit its carbonyl band in the range of $1655-1690 \mathrm{~cm}^{-1}$ [34]. The adsorption bands which appeared at 1722 and $1633 \mathrm{~cm}^{-1}$ were attributed to $\alpha, \beta$-unsaturated carbonyl band [35]. The presence of hydroxyl or oxidation process at $\mathrm{C}=\mathrm{O}$ results in lowering the frequency due to charge transfer complexes of hydroquinone [36]. Quinones can bond potentially to metal ions in three different states: (i) quinone, (ii) its one electron reduced to form semiquinone, and (iii) catechol the two electrons reduced form [37].

The adsorption of Lawsonia inermis on the metal surface greatly depends on its functional groups. Carbonyl $(\mathrm{C}=\mathrm{O})$ and hydroxyl $(-\mathrm{OH})$ as the major Lawsonia inermis constituents improve henna as chelating agent $[38,39]$. The existence of these compounds helps henna molecules to chelate on the surface of AA5083 and hence reduces the surface exposure to the chloride attack where the similar result has been demonstrated [33].

While $\mathrm{C}=\mathrm{C}$ has a lower dipole, it gives a less absorbance intensity compared to $\mathrm{C}=\mathrm{O}$. Usually this functional group can be found at lower frequency that is less than $1600 \mathrm{~cm}^{-1}$. As seen in this IR spectra, $\mathrm{C}=\mathrm{C}$ was found as a weak band at $1448 \mathrm{~cm}^{-1}$ signifying aromatic $\mathrm{C}=\mathrm{C}$ group [36].

The UV-Vis spectra of Lawsonia inermis and its main constituent, 2-hydroxy-1,4-naphthoquinone (HNQ), are depicted in Figure 3. A weak absorption band of Lawsonia inermis at $286 \mathrm{~nm}$ is due to the presence of benzene and quinone with $\pi-\pi^{*}$ electron transition. The attachment of functional group such as hydroxyl $(\mathrm{OH})$ at the benzene ring causes a longer wavelength peak at $342 \mathrm{~nm}$ as shown by the HNQ. Another weak absorption band at $416 \mathrm{~nm}$ is due to the $n-\pi^{*}$ transitions of carbonyl group in the quinone ring [40]. 
3.2. Electrochemical Impedance Spectroscopy (EIS). Electrochemical impedance spectroscopy (EIS) was further conducted in order to investigate the impedance and capacitive behavior at the metal/solution interface. Figure 4(a) shows Nyquist plots obtained from AC impedance measurements of AA5083 at different doses of Lawsonia inermis. The semicircular shapes observed at all concentrations of Lawsonia inermis indicate that there are no changes in corrosion mechanism irrespective of the absence and presence of inhibitor. The size of the semicircle reflects the degree of the inhibitor's impedance. Larger semicircle visualizes higher impedance that contributes to better inhibition performance. As seen, there are a few imperfect semicircles in the plots which are due to the inhomogeneity or surface roughness of the electrode [41-44] and hence lead to the frequency dispersion which is typical for solid metal electrode [45].

Oxidation of aluminum by oxygen, $\mathrm{O}_{2}$, is a fast reaction. Hence, it is impossible to produce an oxide-free surface [46]. The formation of the oxide layer on the aluminum surface due to the interfacial reaction and the adsorption of Lawsonia inermis on the aluminum surface are defined by the single capacitive loop as seen in the plots. The loop is also associated with the charge transfer involved in the corrosion process as well as double layer behavior. All processes, that is, formation of oxide layer and adsorption of inhibitor on the metal surface, are represented by a single capacitive loop due to of the overlapping of these processes.

Theoretically, the dissolution of aluminum in seawater starts when there is a formation of $\mathrm{Al}^{+}$at the metal-oxide interface [47]. The ions then migrate through oxide-solution interface and oxidized to $\mathrm{Al}^{3+}$ which is similar to the work by previous researcher [45]. The presence of inhibitor prominently causes the complexation of the inhibitor with an oxide layer at the aluminum surface. The adsorption that occurs at the interface (metal-oxide-hydroxide-inhibitor) leads to the formation of a complex compound [45, 48]. The chronology of the mechanisms can be determined as follows.

In the anodic half-cell reaction, the dissolution of aluminum takes place according to the following equation [4951]:

$$
\mathrm{Al}_{\mathrm{ads}} \longrightarrow \mathrm{Al}^{3+}+3 e^{-}
$$

The oxygen reduction occurs at cathodic half-cell yielding the following equation:

$$
\frac{1}{2} \mathrm{O}_{2}+2 \mathrm{H}_{2} \mathrm{O}+3 \mathrm{e}^{-} \longrightarrow 3 \mathrm{OH}^{-}+\frac{1}{2} \mathrm{H}_{2}
$$

The overall equation is represented by the following equation:

$$
\mathrm{Al}^{3+}+3 \mathrm{OH}^{-} \longrightarrow \mathrm{Al}(\mathrm{OH})_{3} \cdot 3 \mathrm{H}_{2} \mathrm{O}
$$

In chloride containing solution like seawater, the aluminum anion undergoes hydrolysis:

$$
\mathrm{Al}^{3+}+\mathrm{H}_{2} \mathrm{O} \longleftrightarrow \mathrm{H}^{+}+\mathrm{Al}(\mathrm{OH})^{2+}
$$

Aluminum hydroxide reacts with chloride:

$$
\mathrm{Al}(\mathrm{OH})^{2+}+\mathrm{Cl}^{-} \longrightarrow \mathrm{Al}(\mathrm{OH}) \mathrm{Cl}^{+}
$$

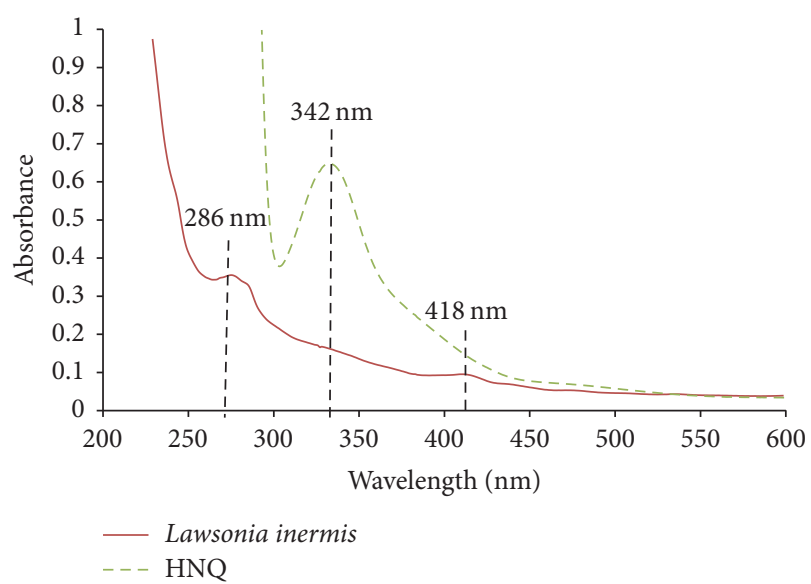

FIGURE 3: UV-Vis spectrum of Lawsonia inermis and its main constituent.

TABLE 3: EIS parameters of aluminum in the absence and presence of Lawsonia inermis.

\begin{tabular}{lcccc}
\hline Concentration $(\mathrm{ppm})$ & $\mathrm{CPE}(F)$ & $R_{\mathrm{ct}}(\Omega)$ & $\mathrm{CPE}(n)$ & $\eta(\%)$ \\
\hline 0 & $4.00 E-04$ & 1102.3 & 0.998 & - \\
200 & $1.40 E-04$ & 5293.8 & 0.998 & 79 \\
400 & $1.60 E-04$ & 9656.7 & 0.998 & 89 \\
600 & $7.80 E-05$ & 14384.0 & 0.996 & 92 \\
800 & $6.20 E-05$ & 9694.2 & 0.997 & 89 \\
1000 & $1.50 E-04$ & 5761.2 & 0.998 & 81 \\
\hline
\end{tabular}

It further reacts with water consequently producing acidic conditions:

$$
\mathrm{Al}(\mathrm{OH}) \mathrm{Cl}^{+}+\mathrm{H}_{2} \mathrm{O} \longleftrightarrow \mathrm{Al}(\mathrm{OH})_{2} \mathrm{Cl}+\mathrm{H}^{+}
$$

The inhibitor acts by adsorbing on the metal surface by displacing the water molecules, hence $[4,47]$ :

$$
\mathrm{Org}(\mathrm{sol})+x \mathrm{H}_{2} \mathrm{O} \longrightarrow \operatorname{Org}(\text { ads }) x \mathrm{H}_{2} \mathrm{O}
$$

Due to positively charge of the inhibitory complex, the repulsion on $\mathrm{H}^{+}$occurs and reduces the hydrogen evolution process.

The value of charge transfer resistance, $R_{\mathrm{ct}}$, constant phase element, CPE, and inhibition efficiency, $\eta$, is tabulated in Table 3. $R_{\mathrm{ct}}$ is the value which represents a measure of electron transfer across the surface and is inversely proportional to the corrosion rate $[52,53]$. The value of $R_{\mathrm{ct}}$ is low in the absence of inhibitor and upon addition of the inhibitor, this value increases until $600 \mathrm{ppm}$. Exceeding this dose causes the value of $R_{\mathrm{ct}}$ to decrease due to the electrostatic repulsion at the metal-inhibitor interface and the remaining inhibitors in the system have likely to form natural aggregate which resulted in the decrease of the inhibition efficiency. Therefore, the optimum value of $R_{\mathrm{ct}}$ and inhibition efficiency $(\eta)$ at $600 \mathrm{ppm}$ indicates that this is the best concentration of Lawsonia inermis in this system.

In this study, CPE is treated as a parallel combination of a pure capacitor and a resistor being inversely proportional 
to the angular frequency where $R_{s}$ is solution resistor and $R_{\mathrm{ct}}$ is charge transfer resistance. A greater depression in Nyquist semicircle diagram is due to the electrode surface irregularity, where the metal-solution interface acts as a capacitor with irregular surface. The impedance of the CPE is expressed as $[50,53,54]$

$$
Z_{\mathrm{CPE}}=\frac{1}{Y_{0}(j \omega)^{n}},
$$

where $Y_{0}$ is the magnitude of the CPE, $j$ is the imaginary unit, $\omega$ is the angular frequency ( $\omega=2 \pi f$, where $f$ is the $\mathrm{AC}$ frequency), and $n$ is the CPE exponent (phase shift).

The value of CPE in this study was in the opposite trend compared to the value of $R_{\mathrm{ct}}$. The decrease of CPE was due to the decrease in the local dielectric constant and/or an increase in the electrical double layer. This phenomenon shows that the inhibitor works by the adsorption process where the water molecule on the metal surface is replaced by the inhibitor.

Two assumptions were made in order to determine the value of CPE in which the first assumption is CPE is due to the surface distribution across an interface. Physically, this model implies that the interface varies in impedance within the plane of interface and would be the case if the oxide film was uniform across the surface. The second assumption is that the film varies through its thickness and the film impedance and is modeled as a series of R-C-R circuits as shown in Figure 5 [55].

The Bode plot represents a wide range of frequency data which can be plotted in one graph. In the Bode plots, $\log |Z|$, and phase angle $\left({ }^{\circ}\right)$ are plotted against $\log f(\mathrm{~Hz})$. A Bode phase in Figure 4(b) shows phase angle plots for aluminum alloy in seawater. In the absence of inhibitor, the phase angle falls nearly at $0^{\circ}$ in the high frequency region. This is a characteristic response to resistive behavior. The presence of Lawsonia inermis has caused the phase angle to fall at higher degree compared to uninhibited sample. The presence of Lawsonia inermis has remarkably altered the system to act more likely a capacitive behavior. At the intermediate frequency, the phase angle of $0 \mathrm{ppm}\left(77.4^{\circ}\right)$, $200 \mathrm{ppm}\left(74.3^{\circ}\right), 400 \mathrm{ppm}\left(74^{\circ}\right), 600 \mathrm{ppm}\left(72.7^{\circ}\right), 800 \mathrm{ppm}$ $\left(72.3^{\circ}\right)$, and $1000 \mathrm{ppm}\left(67.9^{\circ}\right)$ can be observed. A high degree of phase angle in this intermediate frequency region indicates the capacitive behavior of the system. An ideal capacitive behavior will show a $-90^{\circ}$ phase angle. The deviation of from the ideal capacitor $\left(-90^{\circ}\right)$ arises due to the nonideal behavior of the capacitor represented by the control phase element in the circuit (Figure 4).

For a $\log |Z|$ versus $\log f$ plots as depicted in Figure 4(c), the uninhibited system tends to approach zero which represented the resistive behavior at high frequency. All the inhibited systems show a -1 slope which lies from high frequency to intermediate frequency. The magnitude of $\log |Z|$ was found to be the lowest at uninhibited system while the highest magnitude of $\log |Z|$ was found at 600 ppm which indicates that this is the optimum concentration of inhibitor to be used. The capacitive behavior is represented by the liner relationship between the $\log |Z|$ and $\log f$. It is evidence that the addition of Lawsonia inermis has changed the characteristic of the system from resistive behavior to capacitive behavior.
Open circuit potential (OCP) is measured to determine the potential stability of aluminum alloy (5083) in the presence and absence of Lawsonia inermis as shown in Figure 6. To this point, there is no electrical interruption and the net potential measured on electrode is the noble potential [56]. The absence of Lawsonia inermis has caused the electrode to be in the most negative potential region. It is prominent for the electrode to undergo general corrosion in this region compared to the electrode which has more positive potential [57]. Apparently after the addition of Lawsonia inermis, the potential moves towards more positive region. The electrode becomes less active due to the decreased rate of metal dissolution [58].

3.3. Potentiodynamic Polarization (PP). Potentiodynamic polarization study was conducted to distinguish the effect of the inhibitor on the anodic dissolution of AA5083 and cathodic oxygen reduction correspondingly. Table 4 reveals polarization parameters of AA5083 in the presence and absence of Lawsonia inermis. Lawsonia inermis was assumed to act as an anodic inhibitor due to its noticable changes in anodic Tafel branch, $b_{a}$ value. The adsorption of Lawsonia inermis on AA5083 surface restrained the corrosion process by merely blocking the reaction site of the metal surface and consequently reducing the value of $b_{a}[59,60]$.

A graphical data as depicted in Figure 7 shows a prominent shifting in cathodic Tafel branch, $b_{c}$, to a lower value of corrosion current density. The mechanism of the oxygen reduction occurs at the cathodic region which afterward causes the shifting of $b_{c}[45,61]$. It is well known that the changes in $b_{c}$ justify the modification in the cathodic reaction mechanism. Hence, the second assumption was made that Lawsonia inermis act as cathodic inhibitor.

A breakdown potential, $E_{b}$, was prominently seen for the aluminum samples inhibited at $800 \mathrm{ppm}$ and $1000 \mathrm{ppm} . E_{b}$ is a potential at which the anodic polarization curve shows a marked increase in current density, leading to the breakdown of the passive film and pit initiation. For both concentrations, $E_{b}$ is an indicator as a breakdown of the inhibition film which causes a further reduction in inhibition efficiency.

3.4. Adsorption Isotherm. Adsorption isotherm study was conducted to investigate the interaction between the metal and inhibitor as well as the equilibrium of the adsorption. The process of adsorption occurs when liquid or gas accumulates on the surface of a solid or liquid, forming a molecular or atomic film. In general, adsorption isotherm can be divided into two categories. First category occurs when the molecules adsorb but their chemical originality remains unchanged. In this state, the adsorption bond between inhibitor molecule and surface is fairly weak. The molecules may exchange their peer molecules from solution. In contrast, the adsorption bond may be very strong due to charge transfer reaction and result in the formation of new species.

Organic inhibitor adsorption is generally a substitution process of water molecules on the metal surface by inhibitor molecule. There are a few models available for the fitting purposes but the Langmuir adsorption model was found to fit well with the experimental data. The plot of Langmuir 


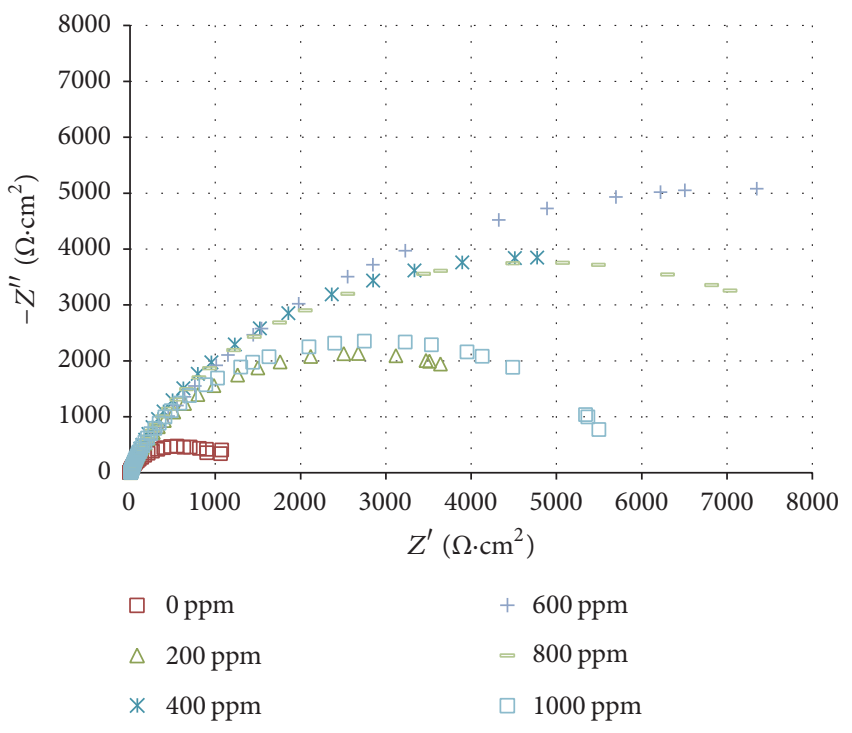

(a)

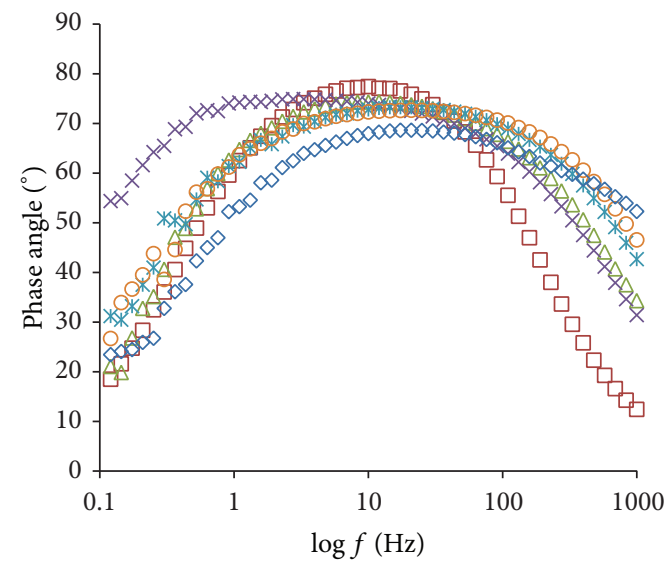
$\square 0 \mathrm{ppm}$
$\triangle 200 \mathrm{ppm}$
$\times 400 \mathrm{ppm}$

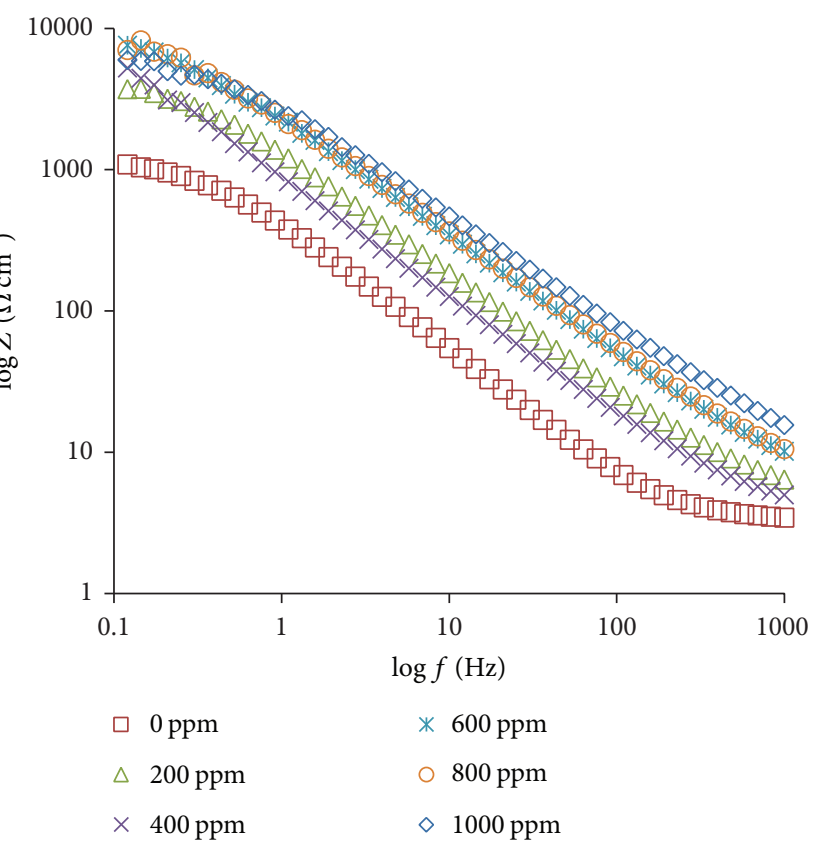

(b)

Figure 4: (a) Nyquist plots, (b) phase angle versus $\log f$ plots, and (c) $\log Z$ versus $\log f$ plots of AA5083 in the absence and presence of inhibitor.

TABLE 4: Nyquist parameters for aluminum alloy in the absence and presence of Lawsonia inermis.

\begin{tabular}{lcccccc}
\hline Concentration $(\mathrm{ppm})$ & $b_{a}(\mathrm{~V} / \mathrm{dec})$ & $b_{c}(\mathrm{~V} / \mathrm{dec})$ & $E_{\text {corr }}(\mathrm{V})$ & $i_{\text {corr }}\left(\mathrm{A} / \mathrm{cm}^{2}\right)$ & \multicolumn{1}{c}{ Corr. rate $(\mathrm{mm} /$ year $)$} & $\eta(\%)$ \\
\hline 0 & 0.27 & 0.26 & -0.72 & $1.71 E-05$ & - & 1.10 \\
200 & 0.09 & 0.12 & -0.73 & $3.56 E-06$ & 0.32 & 0.28 \\
400 & 0.07 & 0.07 & -0.74 & $1.92 E-06$ & 0.09 & 89 \\
600 & 0.07 & 0.12 & -0.76 & $1.12 E-06$ & 0.40 & 83 \\
800 & 0.12 & 0.19 & -0.73 & $1.80 E-06$ & 8.18 \\
1000 & 0.13 & 0.19 & -0.74 & $3.23 E-06$ & 81 \\
\hline
\end{tabular}




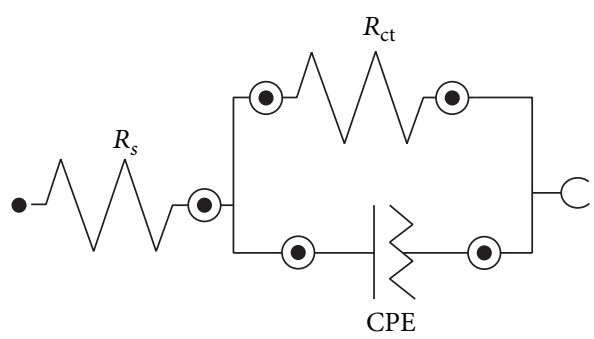

FIGURE 5: The Randles CPE circuit which is equivalent for this impedance spectrum.

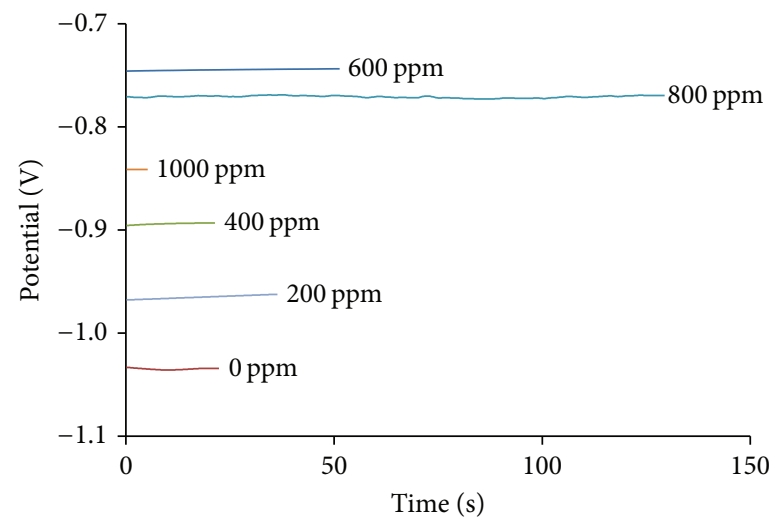

FIGURE 6: OCP of AA5083 in the presence and absence of Lawsonia inermis.

adsorption model is shown in Figure 8 where the value of $\theta$ is equal to $\eta / 100$. The general form of the Langmuir adsorption model is [62]

$$
q_{e}=q_{\max } \frac{K_{L^{C}}}{1+K_{L^{C}}},
$$

where $q_{e}$ is the amount of adsorbate adsorbed on the adsorbent at equilibrium $\left(\mathrm{mol} \mathrm{g}^{-1}\right), q_{\max }$ is the maximum adsorption capacity corresponding to a complete monolayer coverage on the adsorbent surface $\left(\mathrm{mol} \mathrm{g}^{-1}\right), K_{L}$ is the Langmuir constant $\left(\mathrm{dm}^{3} \mathrm{~mol}^{-1}\right)$, and $c_{e}$ is the concentration of adsorbate at equilibrium $\left(\mathrm{mol} \mathrm{dm}{ }^{-3}\right.$ ). The values of $q_{\max }$ and $K_{L}$ can be evaluated from the slope and the intercept of the linear form of the Langmuir equation:

$$
\frac{c_{e}}{q_{e}}=\frac{1}{q_{\max } K_{L}}+\frac{c_{e}}{q_{\max }} .
$$

The free energy change, $\Delta G$, of adsorption is given by $\Delta G=-R T \ln K$, where $R$ is the universal gas constant $\left(8.314 \mathrm{~J} \mathrm{~mol}^{-1} \mathrm{~K}^{-1}\right), T$ is the temperature $(\mathrm{K})$, and $K$ is the equilibrium constant.

Free energy of adsorption, $\Delta G$, values is tabulated in Table 5. The negative value indicates that the adsorption on the metal surface is spontaneous. $\Delta G$ values around $-20 \mathrm{~kJ} /$ mol or lower are consistent with the electrostatic interaction between charged molecule and charged metal surface known as physisorption. If the value is higher, the chemisorptions will occur where the coordinate type of metal bond will be
TABLE 5: The calculated values of $K_{L}$ and $-\Delta G$ gained from two experimental methods (EIS and PP).

\begin{tabular}{lccc}
\hline \multicolumn{2}{c}{$K_{L}, \mathrm{dm}^{3} \mathrm{~mol}^{-1}$} & \multicolumn{2}{c}{$-\Delta G, \mathrm{~kJ} / \mathrm{mol}$} \\
\hline PP & EIS & PP & EIS \\
32.75 & 32.47 & 9 & 9 \\
\hline
\end{tabular}

formed by the charge sharing or transfer from organic molecules to the metal surface. The negative value of $\Delta G$ suggests that the physisorption of inhibitor on the metal surface is a spontaneous process and the adsorbed layer was stable [63].

The adsorption of Lawsonia inermis is favored by the presence of lone pair electrons of $\mathrm{O}$ atom. Lawsonia inermis molecules were adsorbed on the aluminum surface due to electrostatic forces [64-66]. Adsorption of this inhibitor has displaced the water molecules available on the metal surface. The interaction between the organic molecules and the metal surfaces is obtained from various adsorption isotherm models. Assuming that the inhibition was due to the adsorption, $\eta$ was considered as surface coverage on the molecule [67].

The presence of electrons donating group in the inhibitor and delocalized aromatic ring may provide electrostatic adsorption. The higher inhibition efficiency may also suggest the formation of inhibitor surface complex that offers barrier protection. The positively charged surface complex prevents the approach of $\mathrm{H}^{+}$ion by electrostatic repulsion.

Figure 9(a) represents a metal-solution interface for uninhibited system. The charge transfer resistance, $R_{\mathrm{ct}}$, is a corresponding value between the metal and the OHP (outer Helmholtz plane). Without the inhibitor, the ionic layer is dense with the cation which migrates from the bulk solution and accumulates near the OHP due to the polarity of water molecules. Hence the value of CPE is high at this state. Figure 9(b) shows that the protonation of Lawsonia inermis has caused the protonated inhibitor to electrostatically adsorb onto the metal surface through its hydrogen ions. The adsorption of this ion consequently reduces the value of CPE due to the reduction of thin ionic layer at the OHP and at the same time increases the value of $R_{\mathrm{ct}}$ as well.

Lawsonia inermis can be categorized as a cooperative adsorbent due to its ion adsorption on metal/oxide/surface impurities such as chloride ion. For cooperative adsorption, the protonated lawsone can electrostatically adsorb onto the chloride-covered surface through its hydrogen ion as shown in Figure 10. As previously discussed, quinone reduces its one electron to form semiquinone while the available hydrogen ions adsorb electrostatically with chloride ion on the aluminum surface.

3.5. Morphology Study via Scanning Electron Microscope. Figure 11 shows the SEM micrograph of AA5083 at 600 ppm concentration of Lawsonia inermis. An adsorbed white flake can be seen on the metal surface and densely distributed on the metal surface. The adsorption of Lawsonia inermis reduced the free space on metal surface and hence the chloride cannot attack the metal surface. The display figure shows no cracks and pits at this concentration. The employment of Lawsonia 


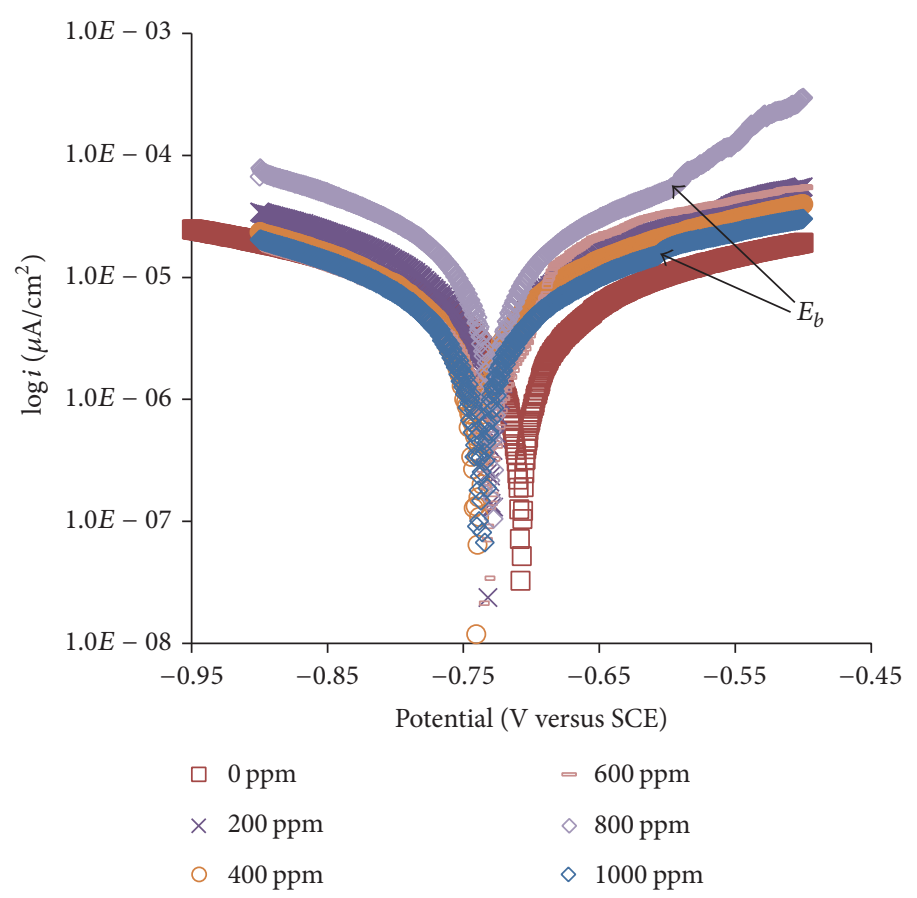

FIgURE 7: Tafel plot of aluminum alloy in the absence and presence of Lawsonia inermis.

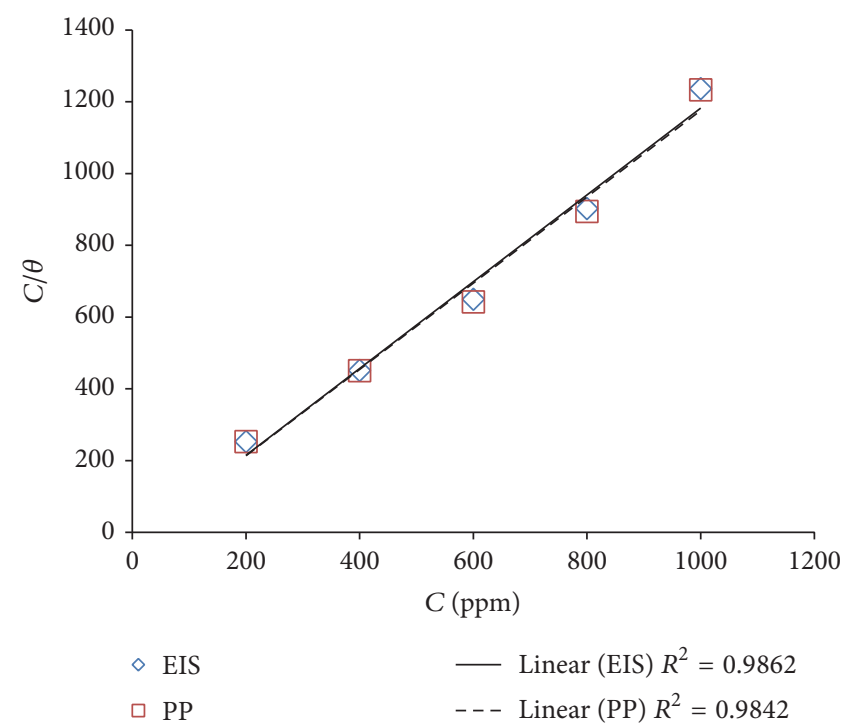

FIGURE 8: Langmuir adsorption model from two experimental methods (EIS and PP) at 30 days of immersion.

inermis as corrosion inhibitor was seen to be successful due to this behavior.

While in the absence of Lawsonia inermis, the surface of AA5083 shows cracks, pits, and heterogenous layers as can be seen in Figure 12. The black spot around the cracks was believed to be the redeposition of copper $(\mathrm{Cu})$ due to the intermetallic reaction with the metal matrix.

\section{Conclusion}

Lawsonia inermis is a possible green material to be developed as corrosion inhibitor for aluminum alloy in marine environment. This is due to the existing of heteroatoms like oxygen and hydrogen which become active centres for adsorption process. Via electrochemical method, the inhibitor was found to enhance the charge transfer resistance, $R_{\mathrm{ct}}$, as the concentration increases. The capacitive behavior of the inhibitor decreases correspondingly to the increasing of concentration signifying that the inhibitor alters the dielectric constant of the layer. $E_{\text {corr }}$ value shifted towards the cathodic region and the difference of $E_{\text {corr }}$ in the absence and presence of inhibitor is $34 \mathrm{mV}$ suggesting that Lawsonia inermis is a mixed type inhibitor. The corrosion current density value, $I_{\text {corr }}$, decreases upon the addition of inhibitor 


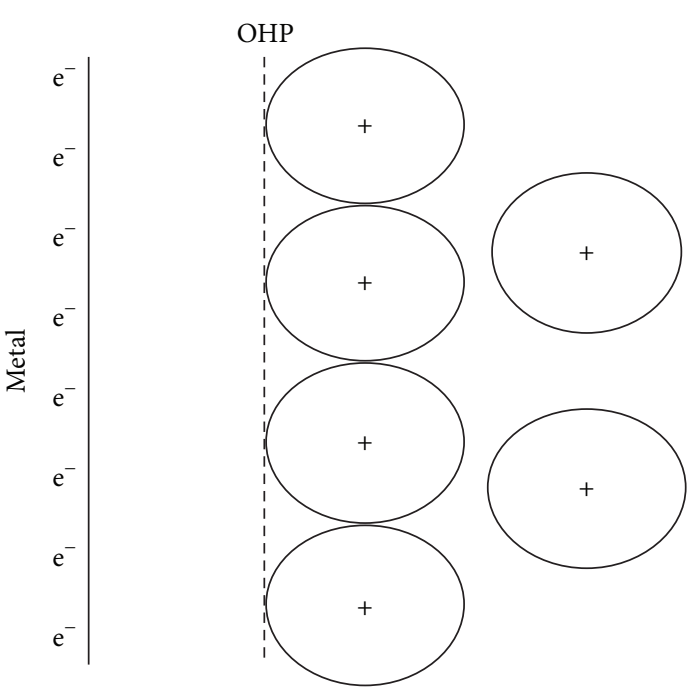

(a)

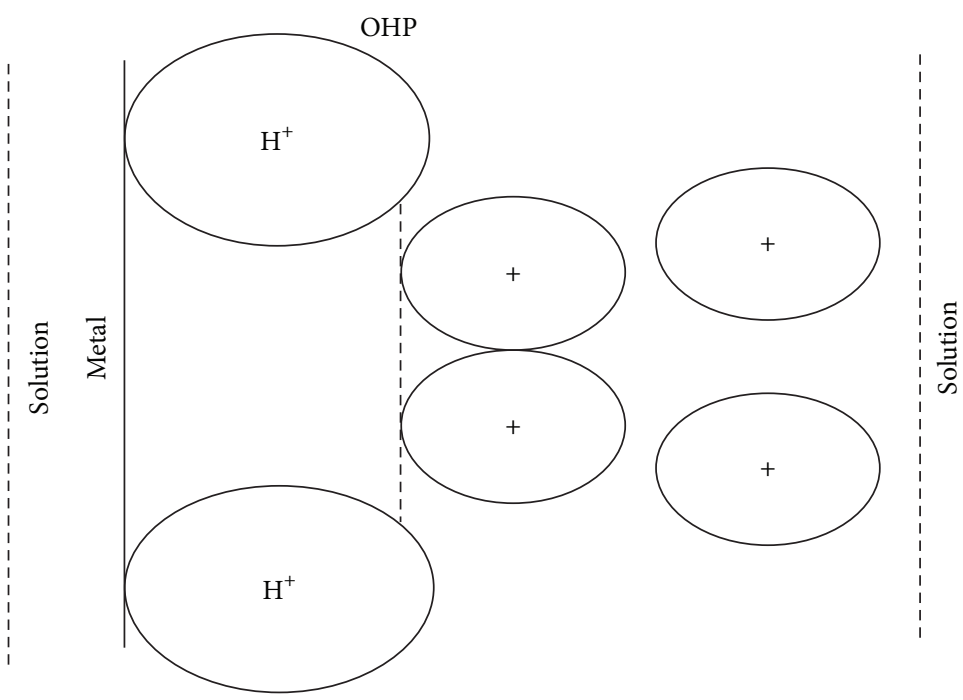

(b)

FIGURE 9: A schematic presentation of (a) metal-solution interface and (b) metal-inhibitor-solution interface.

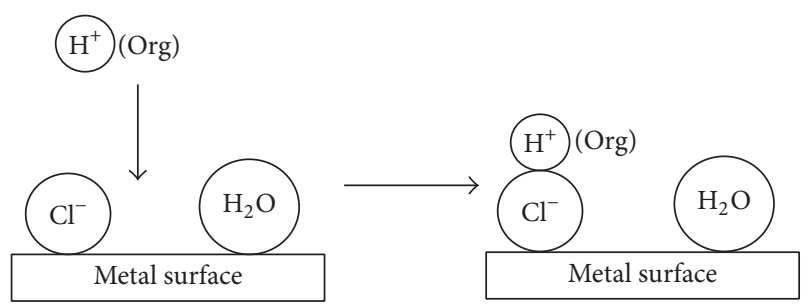

FIGURE 10: The adsorption mechanism of Lawsonia inermis on AA5083.

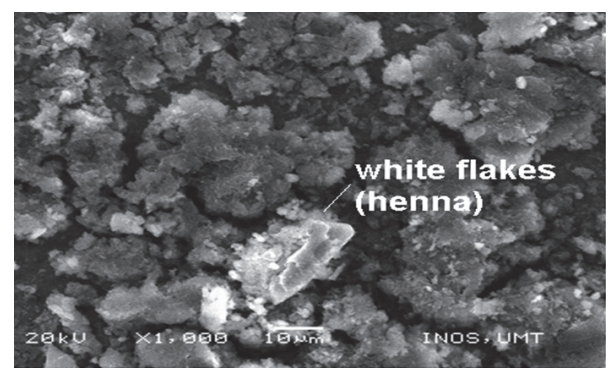

FIGURE 11: SEM micrograph of AA5083 at 600 ppm.

suggesting that the adsorption of the inhibitor has reduced the current passing through the system, and at the same time the inhibitor demonstrates the semiconductor behavior by limiting the current flow through the system.

The adsorption isotherm calculation shows that the inhibitor is well fitted to the Langmuir adsorption model while the value of free energy, $\Delta G$, is less than $-20 \mathrm{~kJ} / \mathrm{mol}$ indicating that the inhibitor performs an electrostatic adsorption which is considered as physical adsorption. All characterizations show that, at $600 \mathrm{ppm}$, the inhibitor is excellently inhibiting the corrosion process and the highest inhibition efficiency is gained at this concentration. Therefore, $600 \mathrm{ppm}$

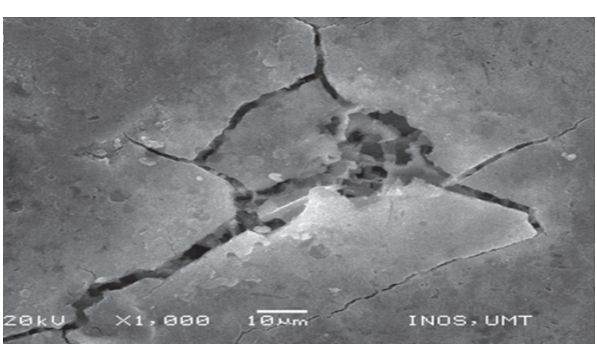

FIGURE 12: SEM micrograph of AA5083 in the absence of Lawsonia inermis.

of Lawsonia inermis is the best concentration to be used as corrosion inhibitor for aluminum alloy in seawater.

\section{Competing Interests}

The authors declare that there is no conflict of interests regarding the publication of this paper.

\section{Acknowledgments}

The authors would like to express their deepest gratitude for the scholarship provided by Ministry of Education, Malaysia (MyPhD), Fundamental Research Grant Scheme (VOT 59210 and VOT 59283), Look East Policy Grant (VOT 53168), and Miss Suria Hani Binti Ibrahim (English Learning Centre) for English language proofread.

\section{References}

[1] S. Ananth, P. Vivek, T. Arumanayagam, and P. Murugakoothan, "Natural dye extract of lawsonia inermis seed as photo sensitizer for titanium dioxide based dye sensitized solar cells," Spectrochimica Acta Part A: Molecular and Biomolecular Spectroscopy, vol. 128, pp. 420-426, 2014. 
[2] S. Ali, T. Hussain, and R. Nawaz, "Optimization of alkaline extraction of natural dye from Henna leaves and its dyeing on cotton by exhaust method," Journal of Cleaner Production, vol. 17, no. 1, pp. 61-66, 2009.

[3] F. Suedile, F. Robert, C. Roos, and M. Lebrini, "Corrosion inhibition of zinc by Mansoa alliacea plant extract in sodium chloride media: extraction, characterization and electrochemical studies," Electrochimica Acta, vol. 133, pp. 631-638, 2014.

[4] D. Prabhu and P. Rao, "Coriandrum sativum L. - a novel green inhibitor for the corrosion inhibition of aluminium in $1.0 \mathrm{M}$ phosphoric acid solution," Journal of Environmental Chemical Engineering, vol. 1, no. 4, pp. 676-683, 2013.

[5] M. Chen, J.-M. Lee, I. S. Nurhati, A. D. Switzer, and E. A. Boyle, "Isotopic record of lead in Singapore Straits during the last 50 years: spatial and temporal variations," Marine Chemistry, vol. 168, pp. 49-59, 2015.

[6] A. Ehsani, M. Mahjani, M. Hosseini, R. Safari, R. Moshrefi, and H. M. Shiri, "Evaluation of Thymus vulgaris plant extract as an eco-friendly corrosion inhibitor for stainless steel 304 in acidic solution by means of electrochemical impedance spectroscopy, electrochemical noise analysis and density functional theory," Journal of Colloid and Interface Science, vol. 490, pp. 444-451, 2017.

[7] A. Singh, I. Ahamad, and M. A. Quraishi, "Piper longum extract as green corrosion inhibitor for aluminium in $\mathrm{NaOH}$ solution," Arabian Journal of Chemistry, vol. 9, no. 2, pp. S1584-S1589, 2012.

[8] E. Ituen, O. Akaranta, A. James, and S. Sun, "Green and sustainable local biomaterials for oilfield chemicals: Griffonia simplicifolia extract as steel corrosion inhibitor in hydrochloric acid," Sustainable Materials and Technologies, vol. 11, pp. 12-18, 2017.

[9] M. Jokar, T. S. Farahani, and B. Ramezanzadeh, "Electrochemical and surface characterizations of morus alba pendula leaves extract (MAPLE) as a green corrosion inhibitor for steel in $1 \mathrm{M}$ $\mathrm{HCl}$," Journal of the Taiwan Institute of Chemical Engineers, vol. 63, pp. 436-452, 2016.

[10] H. Wang, M. Gao, Y. Guo, Y. Yang, and R. Hu, "A natural extract of tobacco rob as scale and corrosion inhibitor in artificial seawater," Desalination, vol. 398, pp. 198-207, 2016.

[11] D. Kirkland and D. Marzin, "An assessment of the genotoxicity of 2-hydroxy-1,4-naphthoquinone, the natural dye ingredient of Henna," Mutation Research-Genetic Toxicology and Environmental Mutagenesis, vol. 537, no. 2, pp. 183-199, 2003.

[12] K. N. Jallad and C. Espada-Jallad, "Lead exposure from the use of Lawsonia inermis (Henna) in temporary paint-on-tattooing and hair dying," Science of the Total Environment, vol. 397, no. 1-3, pp. 244-250, 2008.

[13] S. Salunke-Gawali, L. Kathawate, Y. Shinde, V. G. Puranik, and T. Weyhermüller, "Single crystal X-ray structure of Lawsone anion: evidence for coordination of alkali metal ions and formation of naphthosemiquinone radical in basic media," Journal of Molecular Structure, vol. 1010, pp. 38-45, 2012.

[14] E. C. Jeyaseelan, S. Jenothiny, M. K. Pathmanathan, and J. P. Jeyadevan, "Antibacterial activity of sequentially extracted organic solvent extracts of fruits, flowers and leaves of Lawsonia inermis L. from Jaffna," Asian Pacific Journal of Tropical Biomedicine, vol. 2, no. 10, pp. 798-802, 2012.

[15] I. Abulyazid, E. M. E. Mahdy, and R. M. Ahmed, "Biochemical study for the effect of henna (Lawsonia inermis) on Escherichia coli," Arabian Journal of Chemistry, vol. 6, no. 3, pp. 265-273, 2013.
[16] S. Rajendran, M. Agasta, R. Bama Devi, B. Shyamala Devi, K. Rajam, and J. Jayasundari, "Corrosion inhibition by an aqueous extract of Henna leaves (Lawsonia inermis L)," Zaštita Materijala, vol. 50, pp. 77-84, 2009.

[17] A. Ostovari, S. M. Hoseinieh, M. Peikari, S. R. Shadizadeh, and S. J. Hashemi, "Corrosion inhibition of mild steel in 1 $\mathrm{M} \mathrm{HCl}$ solution by henna extract: a comparative study of the inhibition by henna and its constituents (Lawsone, Gallic acid, $\alpha$-d-Glucose and Tannic acid)," Corrosion Science, vol. 51, no. 9, pp. 1935-1949, 2009.

[18] A. Motalebi, M. Nasr-Esfahani, R. Ali, and M. Pourriahi, "Improvement of corrosion performance of 316L stainless steel via PVTMS/henna thin film," Progress in Natural Science: Materials International, vol. 22, no. 5, pp. 392-400, 2012.

[19] J. Buchweishaija, "Phytochemicals as green corrosion inhibitors in various corrosive media: a review," Tanzania Journal of Science, vol. 35, pp. 77-92, 2009.

[20] K. F. Khaled and N. Hackerman, "Investigation of the inhibitive effect of ortho-substituted anilines on corrosion of iron in $1 \mathrm{M}$ $\mathrm{HCl}$ solutions," Electrochimica Acta, vol. 48, no. 19, pp. 27152723, 2003.

[21] B. Liu, H. Xi, Z. Li, and Q. Xia, "Adsorption and corrosion-inhibiting effect of 2-(2-[2-(4-Pyridylcarbonyl) hydrazono]methylphenoxy)acetic acid on mild steel surface in seawater," Applied Surface Science, vol. 258, no. 17, pp. 6679-6687, 2012.

[22] Z. Hu, L. Wan, S. Lü, P. Zhu, and S. Wu, "Research on the microstructure, fatigue and corrosion behavior of permanent mold and die cast aluminum alloy," Materials and Design, vol. 55, pp. 353-360, 2014.

[23] H.-C. Jiang, L.-Y. Ye, X.-M. Zhang, G. Gu, P. Zhang, and Y.$\mathrm{L}$. Wu, "Intermetallic phase evolution of 5059 aluminum alloy during homogenization," Transactions of Nonferrous Metals Society of China, vol. 23, no. 12, pp. 3553-3560, 2013.

[24] S. Ferraris and L. M. Volpone, "Aluminum alloys in third millennium shipbuilding: Materials, technologies, perspectives," in Proceedings of the 5th International Forum on Aluminum Ships, pp. 1-10, Tokyo, Japan, 2005.

[25] S. Benson, J. Downes, and R. S. Dow, "Load shortening characteristics of marine grade aluminium alloy plates in longitudinal compression," Thin-Walled Structures, vol. 70, pp. 19-32, 2013.

[26] M. Ashjari, A. Mostafapour Asl, and S. Rouhi, "xperimental investigation on the effect of process environment on the mechanical properties of $\mathrm{AA} 5083 / \mathrm{Al}_{2} \mathrm{O}_{3}$ nanocomposite fabricated via friction stir processing," Materials Science and Engineering A, vol. 645, pp. 40-46, 2015.

[27] A. S. Samsudin, W. M. Khairul, and M. I. N. Isa, "Characterization on the potential of carboxy methylcellulose for application as proton conducting biopolymer electrolytes," Journal of NonCrystalline Solids, vol. 358, no. 8, pp. 1104-1112, 2012.

[28] S. Elavarasan and M. Gopalakrishnan, "Synthesis, structural analysis, theoretical studies of some lawsone derivatives," Spectrochimica Acta Part A: Molecular and Biomolecular Spectroscopy, vol. 133, pp. 1-6, 2014.

[29] A. Poursaee, "Potentiostatic transient technique, a simple approach to estimate the corrosion current density and SternGeary constant of reinforcing steel in concrete," Cement and Concrete Research, vol. 40, no. 9, pp. 1451-1458, 2010.

[30] A. Y. El-Etre, M. Abdallah, and Z. E. El-Tantawy, "Corrosion inhibition of some metals using lawsonia extract," Corrosion Science, vol. 47, no. 2, pp. 385-395, 2005. 
[31] Y. Takeda and M. O. Fatope, "New phenolic glucosides from Lawsonia inermis," Journal of Natural Products, vol. 51, no. 4, pp. 725-729, 1988.

[32] N. Uddin, B. S. Siddiqui, S. Begum et al., "Bioactive flavonoids from the leaves of Lawsonia alba (Henna)," Phytochemistry Letters, vol. 4, no. 4, pp. 454-458, 2011.

[33] K. E. Jasim, S. Al-Dallal, and A. M. Hassan, "Henna (Lawsonia inermis L.) dye-sensitized nanocrystalline titania solar cell," Journal of Nanotechnology, vol. 2012, Article ID 167128, 6 pages, 2012.

[34] T. L. Brown, "The infrared carbonyl absorption in some pquinones and related substances," Spectrochimica Acta, vol. 18, no. 4, pp. 1065-1071, 1962.

[35] B. R. Mikhaeil, F. A. Badria, G. T. Maatooq, and M. M. A. Amer, "Antioxidant and immunomodulatory constituents of henna leaves," Zeitschrift fur Naturforschung - Section C Journal of Biosciences, vol. 59, no. 7-8, pp. 468-476, 2004.

[36] M. Slifkin, "Infrared spectra of some organic charge-transfer complexes," Spectrochimica Acta Part A: Molecular Spectroscopy, vol. 29, no. 5, pp. 835-838, 1973.

[37] S. Oramas-Royo, C. Torrejón, I. Cuadrado et al., "Synthesis and cytotoxic activity of metallic complexes of lawsone," Bioorganic and Medicinal Chemistry, vol. 21, no. 9, pp. 2471-2477, 2013.

[38] A. E. Musa and G. A. Gasmelseed, "Characterization of Lawsonia inermis (henna) as vegetable tanning material," Journal of Forest Products \& Industries, vol. 1, no. 2, pp. 35-40, 2012.

[39] W. B. W. Nik, F. Zulkifli, O. Sulaiman, K. B. Samo, and R. Rosliza, "Study of Henna (Lawsonia inermis) as natural corrosion inhibitor for aluminum alloy in seawater," IOP Conference Series: Materials Science and Engineering, vol. 36, no. 1, Article ID 012043, 2012.

[40] A. Fernandez, A. George, and V. K. Remadevi, "Synthesis, characterization, antioxidant, DNA cleavage and cytotoxic studies of amino derivatives of lawsone," International Journal of Phytopharmacy, vol. 1, pp. 36-41, 2013.

[41] L. Li, X. Zhang, J. Lei, J. He, S. Zhang, and F. Pan, "Adsorption and corrosion inhibition of Osmanthus fragran leaves extract on carbon steel," Corrosion Science, vol. 63, pp. 82-90, 2012.

[42] X.-H. Li, S.-D. Deng, and H. Fu, "Inhibition by Jasminum nudiflorum Lindl. leaves extract of the corrosion of cold rolled steel in hydrochloric acid solution," Journal of Applied Electrochemistry, vol. 40, no. 9, pp. 1641-1649, 2010.

[43] N. D. Nam, A. Somers, M. Mathesh et al., "The behaviour of praseodymium 4-hydroxycinnamate as an inhibitor for carbon dioxide corrosion and oxygen corrosion of steel in $\mathrm{NaCl}$ solutions," Corrosion Science, vol. 80, pp. 128-138, 2014.

[44] A. R. Hosein Zadeh, I. Danaee, and M. H. Maddahy, "Thermodynamic and adsorption behaviour of medicinal nitramine as a corrosion inhibitor for AISI steel alloy in $\mathrm{HCl}$ solution," Journal of Materials Science and Technology, vol. 29, no. 9, pp. 884-892, 2013.

[45] X. Li and S. Deng, "Inhibition effect of Dendrocalamus brandisii leaves extract on aluminum in $\mathrm{HCl}, \mathrm{H}_{3} \mathrm{PO}_{4}$ solutions," Corrosion Science, vol. 65, pp. 299-308, 2012.

[46] G. T. Burstein and R. J. Cinderey, "The potential of freshly generated metal surfaces determined from the guillotined electrode-a new technique," Corrosion Science, vol. 32, no. 11, pp. 1195-1211, 1991.

[47] L. Johansson, "Synergistic effects of air pollutants on the atmospheric corrosion of metals and calcareous stones," Marine Chemistry, vol. 30, pp. 113-122, 1990.
[48] M. Metikoš-Huković, R. Babić, and Z. Grubač, "Corrosion protection of aluminium in acidic chloride solutions with nontoxic inhibitors," Journal of Applied Electrochemistry, vol. 28, no. 4, pp. 433-439, 1998.

[49] A. Singh, Y. Lin, W. Liu et al., "Plant derived cationic dye as an effective corrosion inhibitor for 7075 aluminum alloy in 3.5\% $\mathrm{NaCl}$ solution," Journal of Industrial and Engineering Chemistry, vol. 20, no. 6, pp. 4276-4285, 2014.

[50] S. Khireche, D. Boughrara, A. Kadri, L. Hamadou, and N. Benbrahim, "Corrosion mechanism of $\mathrm{Al}, \mathrm{Al}-\mathrm{Zn}$ and $\mathrm{Al}-\mathrm{Zn}-\mathrm{Sn}$ alloys in 3wt.\% $\mathrm{NaCl}$ solution," Corrosion Science, vol. 87, pp. 504-516, 2014.

[51] R. E. Melchers, "Bi-modal trend in the long-term corrosion of aluminium alloys," Corrosion Science, vol. 82, pp. 239-247, 2014.

[52] A. M. Abdel-Gaber, B. A. Abd-El-Nabey, I. M. Sidahmed, A. M. El-Zayady, and M. Saadawy, "Inhibitive action of some plant extracts on the corrosion of steel in acidic media," Corrosion Science, vol. 48, no. 9, pp. 2765-2779, 2006.

[53] M. H. Hussin and M. J. Kassim, "The corrosion inhibition and adsorption behavior of Uncaria gambir extract on mild steel in $1 \mathrm{M} \mathrm{HCl}$," Materials Chemistry and Physics, vol. 125, no. 3, pp. 461-468, 2011.

[54] A. K. Satapathy, G. Gunasekaran, S. C. Sahoo, K. Amit, and P. V. Rodrigues, "Corrosion inhibition by Justicia gendarussa plant extract in hydrochloric acid solution," Corrosion Science, vol. 51, no. 12, pp. 2848-2856, 2009.

[55] R. E. Clegg, "Measurements of the interface between 5083 aluminium and liquid mercury using impedance spectroscopy," Corrosion Science, vol. 52, no. 12, pp. 4028-4034, 2010.

[56] M. Shabani-Nooshabadi and M. S. Ghandchi, "Santolina chamaecyparissus extract as a natural source inhibitor for 304 stainless steel corrosion in $3.5 \% \mathrm{NaCl}$," Journal of Industrial and Engineering Chemistry, vol. 31, pp. 231-237, 2015.

[57] G. Ruhi, O. P. Modi, and S. K. Dhawan, "Chitosan-polypyrrole$\mathrm{SiO}_{2}$ composite coatings with advanced anticorrosive properties," Synthetic Metals, vol. 200, pp. 24-39, 2015.

[58] S. M. Abd El Haleem, S. Abd El Wanees, E. E. Abd El Aal, and A. Farouk, "Factors affecting the corrosion behaviour of aluminium in acid solutions. I. Nitrogen and/or sulphur-containing organic compounds as corrosion inhibitors for $\mathrm{Al}$ in $\mathrm{HCl}$ solutions," Corrosion Science, vol. 68, pp. 1-13, 2013.

[59] X. Li, S. Deng, and X. Xie, "Experimental and theoretical study on corrosion inhibition of oxime compounds for aluminium in $\mathrm{HCl}$ solution," Corrosion Science, vol. 81, pp. 162-175, 2014.

[60] I. Ahamad, R. Prasad, and M. A. Quraishi, "Adsorption and inhibitive properties of some new Mannich bases of Isatin derivatives on corrosion of mild steel in acidic media," Corrosion Science, vol. 52, no. 4, pp. 1472-1481, 2010.

[61] R. Rosliza, W. B. Wan Nik, and H. B. Senin, "The effect of inhibitor on the corrosion of aluminum alloys in acidic solutions," Materials Chemistry and Physics, vol. 107, no. 2-3, pp. 281288, 2008.

[62] S. K. Milonjić, "A consideration of the correct calculation of thermodynamic parameters of adsorption," Journal of the Serbian Chemical Society, vol. 72, no. 12, pp. 1363-1367, 2007.

[63] P. Mourya, S. Banerjee, and M. M. Singh, "Corrosion inhibition of mild steel in acidic solution by Tagetes erecta (Marigold flower) extract as a green inhibitor," Corrosion Science, vol. 85, pp. 352-363, 2014.

[64] P. Mohan and G. P. Kalaignan, "1, 4-Bis (2-nitrobenzylidene) thiosemicarbazide as effective corrosion inhibitor for mild 
steel," Journal of Materials Science and Technology, vol. 29, no. 11, pp. 1096-1100, 2013.

[65] H. Ju, Y. Ju, and Y. Li, "Berberine as an Environmental-Friendly Inhibitor for Hot-Dip Coated Steels in Diluted Hydrochloric Acid," Journal of Materials Science \& Technology, vol. 28, no. 9, pp. 809-816, 2012.

[66] I. Danaee, M. N. Khomami, and A. A. Attar, "Corrosion of AISI 4130 steel alloy under hydrodynamic condition in ethylene glycol + water $+\mathrm{NO}_{2}^{-}$solution," Journal of Materials Science and Technology, vol. 29, no. 1, pp. 89-96, 2013.

[67] E. A. Noor and A. H. Al-Moubaraki, "Thermodynamic study of metal corrosion and inhibitor adsorption processes in mild steel/1-methyl-4[4/(-X)-styryl pyridinium iodides/hydrochloric acid systems," Materials Chemistry and Physics, vol. 110, no. 1, pp. 145-154, 2008. 

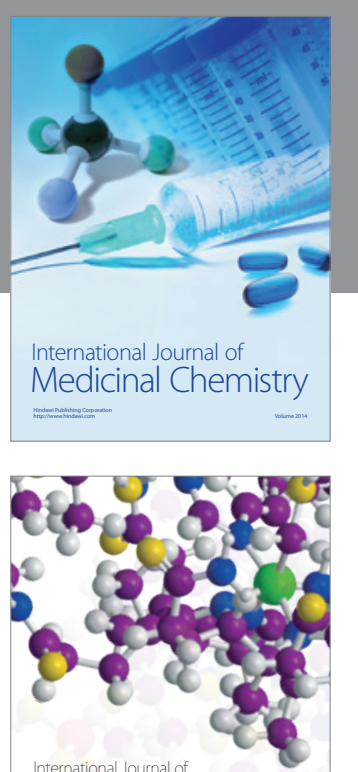

Carbohydrate Chemistry

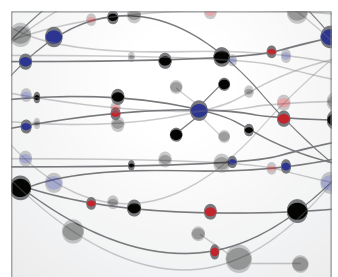

The Scientific World Journal
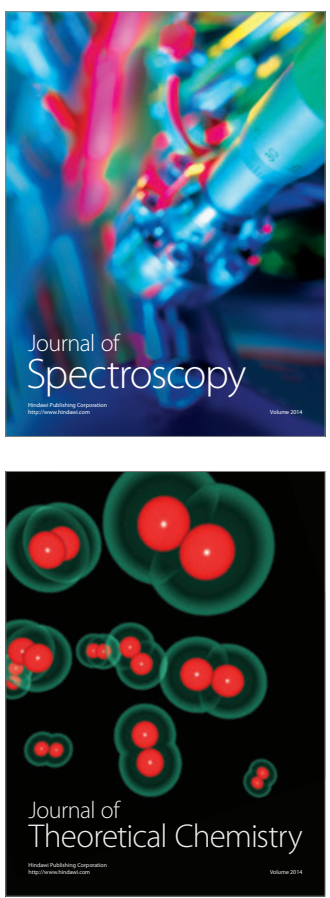
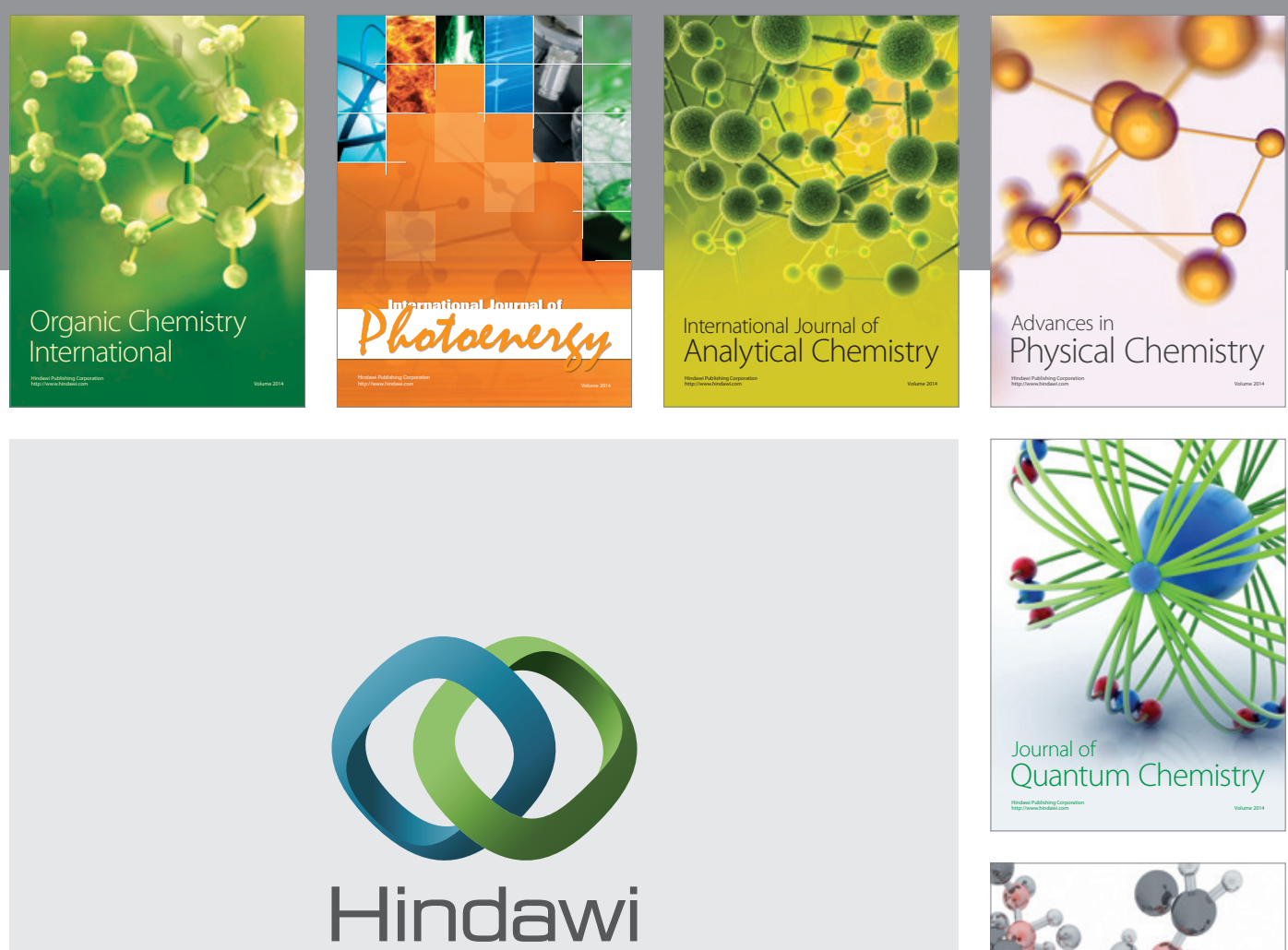

Submit your manuscripts at

https://www.hindawi.com

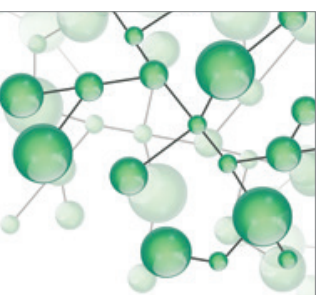

International Journal of

Inorganic Chemistry
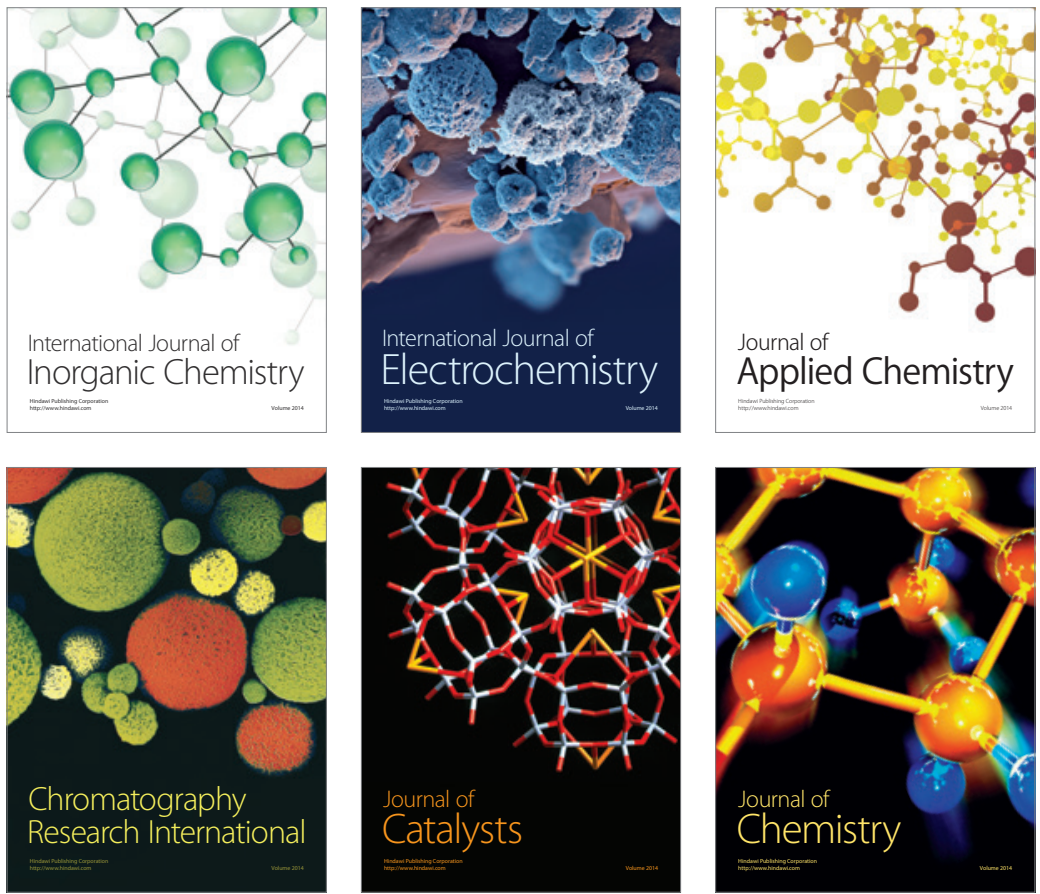

Journal of

Applied Chemistry
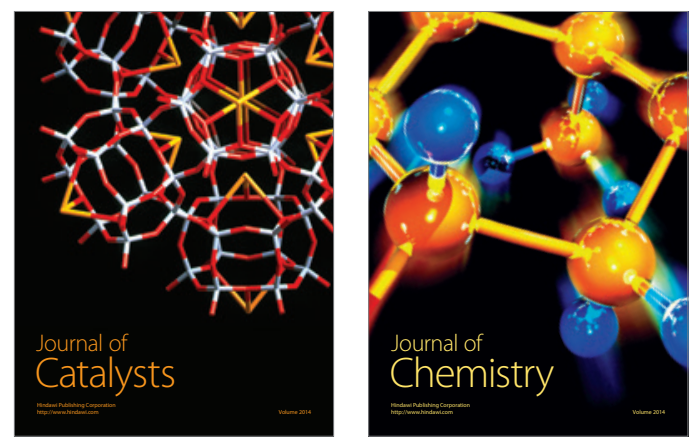
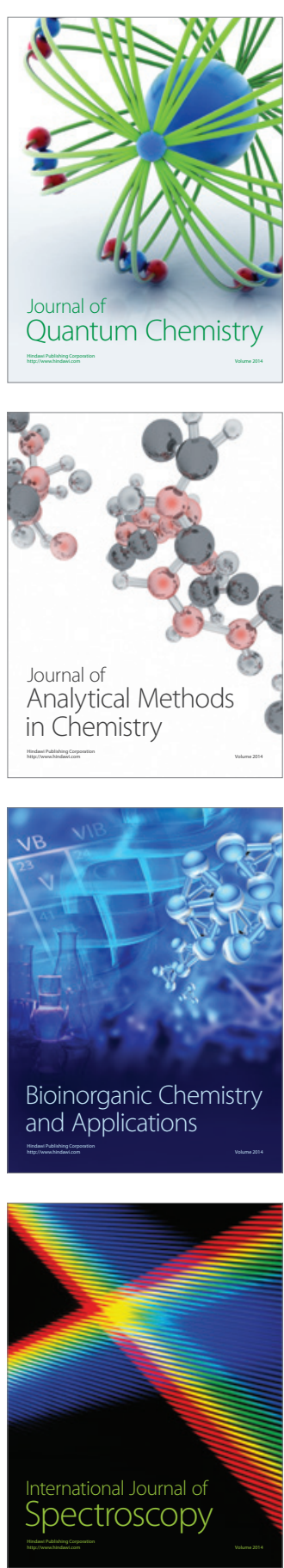